\title{
Molecular Survey of Babesia spp. and Anaplasma phagocytophilum in Roe Deer from a Wildlife Rescue Center in Italy
}

\author{
Alessandra Cafiso ${ }^{1, * \mathbb{C}}$, Chiara Bazzocchi ${ }^{1}$, Martina Cavagna ${ }^{1}$, Elena Di Lorenzo ${ }^{1}$, Valentina Serra ${ }^{1} \mathbb{D}$, \\ Riccardo Rossi ${ }^{2}$ and Stefano Comazzi ${ }^{1}{ }^{1}$
}

1 Department of Veterinary Medicine, University of Milan, 26900 Lodi, Italy; chiara.bazzocchi@unimi.it (C.B.); marti.cavagna7@gmail.com (M.C.); elena.dilo@gmail.com (E.D.L.); valentina.serra@unimi.it (V.S.); stefano.comazzi@unimi.it (S.C.)

2 Piacenza Wildlife Rescue Center, 29120 Niviano di Rivergano, Italy; info@piacenzawildlife.org

* Correspondence: alessandra.cafiso@unimi.it; Tel.: +39-02-503-34533

Citation: Cafiso, A.; Bazzocchi, C.; Cavagna, M.; Di Lorenzo, E.; Serra, V.; Rossi, R.; Comazzi, S. Molecular Survey of Babesia spp. and Anaplasma phagocytophilum in Roe Deer from a Wildlife Rescue Center in Italy. Animals 2021, 11, 3335. https:// doi.org/10.3390/ani11113335

Academic Editor: Rita Tinoco Torres

Received: 5 November 2021

Accepted: 19 November 2021

Published: 22 November 2021

Publisher's Note: MDPI stays neutral with regard to jurisdictional claims in published maps and institutional affiliations.

Copyright: (c) 2021 by the authors. Licensee MDPI, Basel, Switzerland. This article is an open access article distributed under the terms and conditions of the Creative Commons Attribution (CC BY) license (https:// creativecommons.org/licenses/by/ $4.0 /)$.
Simple Summary: Roe deer, whose populations are increasing and expanding throughout Europe, are suitable hosts for the maintenance of a variety of infectious tick-vectored microorganisms, that can infect both animals and humans. In this study the presence of tick-transmitted pathogens was investigated in roe deer recovered by a wildlife rescue center based in Italy. This kind of samples represents a convenient material for investigations under several aspects for both animals and researchers. Notably, no live trapping or killing are required to obtain samples, as they are collected in the context of the rescue activities and aimed to frame the health status of the animal. The investigated blood samples showed high positive rates to typical roe deer-related microorganisms (such as Babesia capreoli), and to the zoonotic agent Babesia venatorum. Roe deer were also positive to Anaplasma phagocytophilum strains mainly considered apathogenic or limited to wild ungulates. The obtained results underline the importance of a constant investigation on circulating tick-borne pathogens in roe deer, and generally speaking, in wild animal species, due to their potential role as a key factor in the endemic cycle of important infectious agents for domestic and wild animals, as well as humans.

Abstract: Babesia ssp. and Anaplasma spp. are tick-borne microorganisms representing a possible health risk for domestic and wild animals, as well as humans. Roe deer serve as a suitable reservoir host for some species ascribed to Babesia spp. and Anaplasma phagocytophilum taxa, also due to its important role in the maintenance of large populations of Ixodes ricinus, the main tick vector of these pathogens in Europe. Roe deer populations have been recently expanding throughout Europe, namely in Italy. However, the collection of samples from free-ranging wild animals for diagnostic investigations often includes several practical issues. This problem can be overcome using samples provided by wildlife rescue centers making them available for investigations following routine analyses. The presence of Babesia spp. and Anaplasma spp. in blood samples of 43 roe deer rescued by a wildlife rescue center in Emilia-Romagna region (Italy) was molecularly investigated. PCR screening revealed the presence of at least one pathogen in $86.05 \%$ of the animals, while co-infection occurred in $18.92 \%$ of the tested individuals. Zoonotic Babesia venatorum was found in $6.98 \%$ of the samples, while Babesia capreoli and Anaplasma phagocytophilum were detected in $74.42 \%$ and in $20.93 \%$, respectively. No hematological signs compatible with clinical anaplasmosis or piroplasmosis, as well as absence of intracellular circulating microorganisms in blood smears, were observed, suggesting asymptomatic infection in the tested animals. These results confirm the usefulness of wild rescued animals as convenient source of biological samples for tick-borne pathogens investigation and the role of roe deer as a key factor in the endemic cycle of Babesia species and A. phagocytophilum.

Keywords: Babesia; Anaplasma phagocytophilum; rescued animal; roe deer; zoonosis; tick-borne pathogen; wildlife; northern Italy; rescued animal 


\section{Introduction}

Over the last decades, increasing interest has been raised towards tick-borne diseases, which are considered to become one of the most important human and veterinary health concerns in the future [1]. In Europe, the most important tick species involved in the transmission of tick-borne pathogens is Ixodes ricinus, a hard tick characterized by a triphasic lifecycle and low host specificity, which is able to vehicle a variety of pathogenic microorganisms, such as viruses, bacteria and protozoa [2]. The distribution and abundance of I. ricinus is currently expanding both at latitudes and altitudes due to several factors, including climate changes and variable land managing [2,3]. Wild ungulates are considered among the most important hosts for the maintenance of I. ricinus populations [4]. In many European countries, as the case of northern Italy, wild ungulates populations are currently expanding, partly due to wildlife management programs and increased number of animals in areas now inhabited by humans [5]. This is the case of roe deer (Capreolus capreolus), a species that faced a massive decline at the beginning of the 19th century, due to over-hunting and deforestation, and that is now re-expanding thanks to the abandonment of crops in upland and mountain areas, repopulation programs, hunting regulations and to its high environmental adaptability, with an increased population in Italy of $201.4 \%$ from 1984 to 2004 [6-9]. Roe deer, besides being considered as one of the most important host species for ticks, plays an important role in maintaining several tick-transmitted pathogens, which have raised human and veterinary health concern especially in the last decades [2]. Among these, Anaplasma phagocytophilum, whose main vector in Europe is I. ricinus, is the etiological agent of tick-borne fever (TBF) in domestic ruminants and granulocytic anaplasmosis in several animal species, humans included [10,11]. Typical hematological signs of A. phagocytophilum infection are neutropenia and leukopenia, while clinical signs like weakness, fever, inappetence, constipation, icterus, dehydration, increased infertility have been observed, for example, in cattle and sheep [12,13]. Several studies pointed out that wild ruminants, in particular roe deer, can be the reservoir hosts for this tickborne agent $[14,15]$. Ixodes ricinus can also vector piroplasms of the genus Babesia, a taxon encompassing intra-erythrocytic parasites of the phylum Apicomplexa, with more than 100 ascribed species able to infect domestic and wild animals [16]. Clinical manifestations of babesiosis can vary in severity from asymptomatic to severe and sometimes fatal infections, also depending on the species, and symptoms can include anemia, splenomegaly, hepatomegaly, jaundice; haematological signs include hemolytic anemia and thrombocytopenia [17]. Several Babesia species have been reported in roe deer, including two zoonotic agents (Babesia divergens, Babesia venatorum), and Babesia capreoli, currently considered as a specific roe deer parasite $[15,17,18]$.

Due to the role of roe deer as reservoirs of tick-transmitted agents, the screening of these ungulates is crucial to perform studies focused on tick-borne pathogens and evaluate the potential risk for human and animal health. However, samplings from freeranging wild animals often present several practical issues, such as the time required for sampling, permissions, ethical aspects, high costs, trapping procedures, etc. [19,20]. On the contrary, rescued animals represent a useful and convenient source for biological samples and data from wildlife, without requiring demanding methods of hunting or trapping, that can in turn result in stressful conditions for the animals and need much organization and logistics resources for the researchers. Roe deer populations are increasing in density due to the abandonment of rural areas, changes in human land use, restocking and lack of predators $[6,7,21]$. Additionally, an increasing geographic expansion of roe deer towards cultivated areas and densely populated and peri-urban territories has been recently reported $[7,22,23]$. In this context, there is a growing probability of contact between humans and wildlife that in turn intensifies the potential for direct lethal effects (vehicle collisions, predation by dogs, etc.) [24].

Since roe deer are among the most common cervid species in Italy [25], they are frequently recovered by wildlife rescue centers [26]. For these reasons rescued roe deer 
represent a convenient and easy-to-access source of samples aimed at investigating tickborne related pathogens.

In this study the presence and co-infection of tick-transmitted microbial agents A. phagocytophilum and Babesia spp. were investigated in blood samples obtained from wild roe deer rescued by the Piacenza Wildlife Rescue Center (Italy).

\section{Materials and Methods}

\subsection{Samples Collection}

Blood samples from roe deer, of different sexes and ages, rescued in the province of Piacenza (Emilia-Romagna region) during 2019, were obtained from the Piacenza Wildlife Rescue Center (CRAS; Niviano di Rivergano, Italy). Samples were collected in the context of the rescue activities and were aimed to frame the health status of the animal before taking any medical decision; the leftover part of the blood samples were used for the purpose of the present research. According to the guidelines of the authors' institution, a formal approval of the Ethical Committee was not required (EC decision 29 October 2012, renewed with the protocol no. 02-2016). The reasons for the admission varied (e.g., car road accident, trauma due to combine harvesters or other causes like predation or imprinting). Blood was withdrawn from the cephalic vein within $2 \mathrm{~h}$ of arrival to the center, and put in EDTA-coated tubes for complete blood cell analysis. Blood smears were obtained immediately, stained with May Grünwald-Giemsa and examined under a light microscope (magnification $100 \times$ ). The leftover part of blood samples was destined to molecular analyses and stored at $-80{ }^{\circ} \mathrm{C}$ until use.

\subsection{Molecular Analyses}

DNA was isolated from $200 \mu \mathrm{L}$ of whole blood using the DNeasy Blood and Tissue Kit (Qiagen, Hilden, Germany) following the manufacturer's instructions. Extracted DNA samples were quantified using a spectrophotometer (Nanodrop ND 1000, Thermo Scientific, Wilmington, DE, USA) and stored at $-80^{\circ} \mathrm{C}$ until further analyses. Quality of the DNA extraction was assessed by amplifying a fragment of the $12 \mathrm{~S}$ rDNA gene of C. capreolus [27].

All samples were screened for the presence of Babesia spp. DNA using a qualitative PCR targeting a 411-452 bp region of the 18S rDNA gene [28]; the presence of Anaplasma spp. was assessed using a qualitative PCR targeting a $\sim 490 \mathrm{bp}$ region of the $16 \mathrm{~S}$ rDNA gene and which detects Ehrlichia and Anaplasma species [29]. PCR products were loaded on agarose gel, bands corresponding to the positive amplicons were excised and purified with Wizard ${ }^{\circledR}$ SV Gel and PCR Clean-Up System Kit (Promega, Madison, WI, USA) following the manufacturer's instructions, and subsequently bidirectionally Sanger sequenced. The obtained sequences were manually curated, assembled using SeaView 4.7 (PRABI-Doua, Lyon, France) [30], and deposited in GenBank. After NCBI Blast comparison of the obtained sequences with those available in GenBank, unresolved B. divergens / B. capreoli positive samples were subjected to a PCR protocol described elsewhere [31] to evaluate the presence of the three-base differences in the $18 \mathrm{~S}$ rDNA that can discriminate the two species [17].

\subsection{Phylogenetic and Statistical Analyses}

Phylogenetic inference was performed using Maximum Likelihood method and Kimura 2-parameter model [32] chosen according to the BIC criterion and conducted with Mega X software version 10.1.8 (MEGA, Pennsylvania, PA, USA) [33].

Prevalence was calculated with confidence intervals at 95\%. Statistical significance between positivity of males and females to Babesia spp., Anaplasma spp., and co-infections, was inferred using Fisher's exact test; the association between the presence of Babesia spp. and Anaplasma spp. was analyzed using Chi-squared test. The online tool "Social Science Statistics ${ }^{\circledR \prime \prime}$ Calculator was used for statistical inference (www.socscistatistics.com; accessed on 26 October 2021) [34]. 


\section{Results}

A total of 43 blood samples from as many rescued roe deer individuals (21 females and 22 males) were collected by the Piacenza Wildlife Rescue Center. Complete blood cell count did not show hematological signs compatible with clinical anaplasmosis (leukopenia and neutropenia) or piroplasmosis (hemolytic anemia) (data not shown). The main hematological abnormalities found in were mainly attributable to the cause of the recovery (blood loss anemia) or to the stress due to the capture and pain (neutrophilia and lymphopenia). Blood smears observation showed no parasitic inclusions in any analyzed sample.

All the extracted DNA samples tested for roe deer 12S rDNA gene showed bright PCR bands when run in agarose gel, suggesting good DNA quality and absence of PCR inhibition. Overall, 37 out of 43 analyzed DNA samples (86.05\%; 95\% CI: 75.69-96.40) resulted positive to at least one pathogen and 7 of them $(18.92 \% ; 95 \%$ CI: $6.30-31.54)$ showed simultaneous infection with the two investigated microbial agents. In detail, 35 samples (81.4\%; 95\% CI: 69.76-93.03) resulted positive to Babesia spp., and 9 samples (20.93\%; $95 \%$ CI: 8.77-33.09) were positive to Anaplasma spp.

All the obtained Babesia spp. 18S rDNA amplicons were sequenced, and 32 out of 35 sequences showed $100 \%$ unresolved identity with B. divergens / B. capreoli. Additional PCR analyses revealed $100 \%$ identity with $B$. capreoli sequence FJ944827 (showing an overall prevalence of $74.42 \%$; 95\% CI: 57.28-91.56). Three samples (overall prevalence 6.98\%; 95\% CI: 0.00-16.98) showed 100\% identity with several B. venatorum sequences present in GenBank (e.g., MG344777). The obtained Babesia spp. sequences were deposited in GenBank under the accession numbers OK598971-OK598972. No Babesia mixed infections were observed in the same sample.

Sequencing of the nine positive Anaplasma spp. amplicons showed identity with A. phagocytophilum, and the subsequent phylogenetic analysis highlighted the presence of two sequence variants (Figure 1). One isolate (accession OK597195; two positive samples) clustered with $A$. phagocytophilum variant "V" group; the second isolate (accession OK597196; seven positive samples) clustered with variant " $Y^{\prime \prime}$ group [15,35].

No significant differences were observed in infection rates between females and males regarding the investigated pathogens or co-infections $(p>0.05)$, but a significant association between the two pathogens in the infected hosts was observed $(p<0.05)$. 


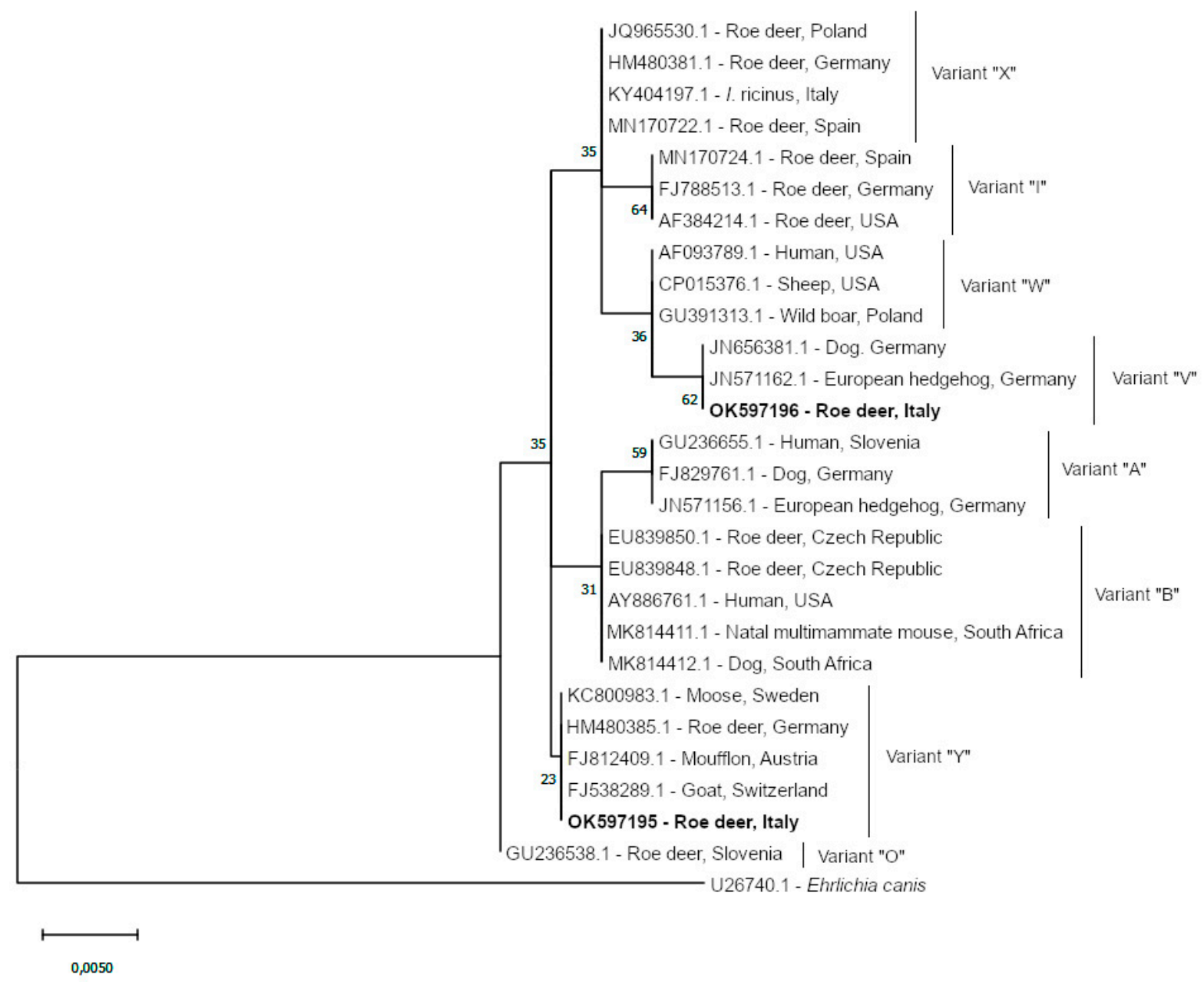

Figure 1. Maximum likelihood phylogenomic tree of the partial 16S rDNA gene of A. phagocytophilum obtained with MEGA $X$ [33] and Kimura 2-parameter [32] model showing clustering variants (100 replicates; bootstrap values are indicated at the nodes). Ehrlichia canis $16 \mathrm{~S}$ rDNA sequence (U26740) was used as outgroup. The tree is drawn to scale, with branch lengths measured in the number of substitutions per site. Isolates identified in this study are indicated in bold font.

\section{Discussion}

In this study, the presence of Babesia spp. and Anaplasma spp. in rescued roe deer was investigated. The overall prevalence of Babesia spp. in roe deer $(81.4 \%)$ is comparable to other studies performed in Italy, specifically in areas close to the study site [36]. Additionally, the obtained results are in line with surveys performed in other European countries [37-40]. B. capreoli was the most common detected Babesia species. It must be noted that $B$. divergens is widely overestimated in wildlife due to its erroneous overlap with B. capreoli $[41,42]$. For this reason, accurate molecular analyses aimed to the discrimination of $B$. divergens/B. capreoli need to be performed for a precise evaluation of human and animal health risk related to the presence of these two piroplasms. The two species are serologically indistinguishable and require sequencing analyses of the $18 \mathrm{~S}$ rDNA gene amplicons for the identification of the three-nucleotide variation that characterizes each species [17]. A previous study performed on roe deer in a close area revealed the presence of $B$. divergens-related sequences, clustering with the single B. capreoli gene sequence (AY726009) available at that time [36]. However, the mentioned survey was prior to the redescription of B. capreoli $[17,43]$, and no related $18 \mathrm{~S}$ rDNA gene entries, systematically able to differentiate B. divergens and B. capreoli, were available for a precise classification [17]. In the light of the three-nucleotide variation described between the two considered species, previous results concerning $B$. divergens-like findings in the study area should be reconsidered to obtain a 
clear epidemiological picture of Babesia species in the area. Despite the apparently lack of pathogenicity for human and domestic animals, B. capreoli appears as a possible concern for some wildlife species, occasionally causing disease in wild ungulates [38]. Deeper investigations on babesiosis in wildlife are needed, since limited information on few wild species are currently available $[38,44]$. Clinical babesiosis is commonly observed to be rare in free-ranging wild ruminants, and asymptomatic babesiosis seems to be the most widespread condition [45]. However, several studies reported cases of clinical signs of babesiosis in roe deer [38], with symptoms that included high parasitemia prevalence [17]. In the present study, despite the high prevalence of B. capreoli in the tested animals, hematological signs compatible with a possible clinical disease were not found in any of the cases. This result hints that the tested roe deer were healthy carriers of B. capreoli, and that infection might be endemic rather than emerging. In addition, the hypothesis of the role of roe deer as reservoir host for $B$. capreoli, with asymptomatic infections that rarely induce clinical symptoms, is supported. Since wildlife is recognized for its role in the transmission of pathogens to livestock, and ungulates share many pathogens with cattle, beyond acting as possible reservoirs and sustaining tick populations [46], attention should be paid to those areas with high $B$. capreoli-positive rates. Indeed, domestic animals, such as sheep, have been reported as hosts for B. capreoli [42]. On the contrary, B. venatorum, which has been previously identified in ticks and roe deer in neighboring areas [31,36,47], showed prevalence rates in accordance with former published data [36]. Infection with $B$. venatorum, whose primary host is considered to be roe deer, has been reported in several human cases in Europe and China, originally in immunocompromised patients, and, more recently, also in immunocompetent ones $[48,49]$. Further investigations on this zoonotic agent should be carried out to evaluate the actual health risk for humans, domestic and wild animals. Furthermore, a previous study reported the presence of $B$. venatorum more often in roe deer individuals found dead, suggesting this Babesia species as an additional cause of death $[14,50]$. However, hematological parameters of the $B$. venatorum-positive individuals did not show any clinical sign of infection.

Anaplasma phagocytophilum was detected in roe deer with a prevalence of $20.93 \%$, in line with prevalence rates found in other European countries, ranging from $9.6 \%$ to $100 \%[14,39,40,51]$. In particular, several studies performed on spleen have provided very high prevalence rates as already stated elsewhere [14,51]; for this reason the observed prevalence in the study area could be underestimated. Unfortunately, due to the type of recruitment of roe deer (rescued animals) only blood was obtained, and no information about the possible presence of the parasite in other tissues may be obtained. Additionally, prevalence of $A$. phagocytophilum in other Italian regions showed higher prevalence rates in different wild ungulates [52-54], but the use of different molecular approaches could have influenced the outcoming results. Roe deer is considered to play an important role in spreading A. phagocytophilum [15,35], as it is also considered one of the major actors in the maintenance of I. ricinus populations [55,56]. Transovarial transmission of A. phagocytophilum has been described as absent or inefficient in I. ricinus [57], hence the role of reservoir hosts, as the case of roe deer, which are able to maintain large tick populations, becomes crucial for the spread of anaplasmosis [51]. Roe deer is able to migrate easily for long distances while carrying variable tick loads, thus promoting the spreading of ticks in several areas [15] and, in turn, enhancing the spreading of potential zoonotic agents. Different gene targets have been employed in determining variants and strains of A. phagocytophilum, such as ankA, msp4, groEL and $16 \mathrm{~S}$ rDNA [40,58]. Compared to other genes, the $16 \mathrm{~S}$ rDNA represents a more conserved genetic region with a limited genetic variability, thus resulting uninformative for precise identification of genetic variants and for host association inferences $[35,39]$. Although the $16 \mathrm{~S}$ rDNA gene is not considered a good discriminatory marker for A. phagocytophilum [59], some authors reported it as a useful starting point for the discrimination of variants causing granulocytic anaplasmosis from non-pathogenic ones [35]. The most frequent sequence variant observed in this study (seven out of nine positives) clustered with sequences belonging to A. phagocytophilum variant 
" $Y$ ", which has been previously related to wild ruminants, mainly cervids. It is one of the two most widespread variants in Europe and is currently considered apathogenic [35,39]. The less prevalent $A$. phagocytophilum sequence variant identified in this work clustered with variant " $V$ " which has been classified as potentially specific for wild ruminant, and was detected previously in roe deer, and also in dogs [15,39]. Taking into account the results concerning the isolates detected in this study, attention should be paid to roe deer as contributors to the endemic cycle of possible pathogenic variants of A. phagocytophilum for wild ungulates and, potentially, domestic animals. However, further analyses should be performed using additional molecular markers other than $16 \mathrm{~S}$ rDNA, in order to deeper investigate the A. phagocytophilum variants circulating in the area and precisely characterize those that could represent a health threat for animals and humans.

Overall, no gender-dependent infection rates were observed for both pathogens, as well as for co-infections, supporting similar data for roe deer previously reported $[39,50]$. In this study, $18.92 \%$ of the tested individuals showed co-infection of Babesia spp. and A. phagocytophilum, which is significantly lower compared to other surveys performed in roe deer in Europe $[15,39,40,60]$. Co-infection of the two pathogens in wild ungulates has been matter of investigations in the recent years for their possible interactions in the mammalian host [41]. Even though the potential synergic role between the two pathogens needs to be unraveled, several studies have already pointed out the generalized immunosuppressive activity of $A$. phagocytophilum in the host, which affects the number and functions of lymphocytes and granulocytes in peripheral blood. Thus, infection with A. phagocytophilum could put the animal at risk for increased susceptibility of infection by various Babesia species $[11,51,61]$. Microbial co-infections in vertebrate hosts, as well as in tick vectors, require growing attention since synergic and antagonistic interactions could in turn promote, worsen or modify the onset and clinical signs of diseases caused by a single pathogen.

As already stated, despite the high prevalence of the investigated pathogens, no hematological signs were compatible with a possible clinical disease. Blood smears and results of complete blood cell count showed no presence of any circulating microorganism, suggesting a transient and limited parasitemia. The absence of Babesia cells in blood smears was already observed in previous surveys, but parasites were eventually detected in blood following few days of autologous cell culture [62], hinting that more sensitive techniques (as the case of molecular analyses) are required for the detection. Hematological parameters highlighted the absence of possible pathologies and indicated the presence of an asymptomatic infection. Nonetheless, it is not excludible that positivity to these tick-borne pathogens could have played a risk factor for roe deer in being more subjected to car accidents, predation, or traumas.

\section{Conclusions}

In summary, this study highlights the valuable contribution of rescued animals as a source of samples for investigations on tick-borne and zoonotic pathogens. Wildlife rescue centers represent precious and convenient sources of material to evaluate the current health status and condition of the wildlife populations, requiring a minimal sampling effort for both animals and researchers. However, the usefulness of this data can mainly be attributed to those species which are more widespread and thus more commonly rescued by these centers, as the case of roe deer in Europe.

This work also confirms roe deer as one of the main possible reservoir hosts for infectious agents that can affect wildlife, as the case of B. capreoli. Hematological data of wildlife (namely roe deer) in relation to Babesia spp. and A. phagocytophilum are limited, and this field should be deeper investigated for a better comprehension of the infection mechanisms in wild animals. In addition, roe deer has been confirmed as reservoir host for zoonotic agents (or potential ones) as the case of $B$. venatorum. Co-infection between Babesia spp. and A. phagocytophilum requires further investigations to understand which of the two pathogens could influence the infection of the other and in which way. The current expansion of roe deer populations throughout Europe, that in turn results in 
the possible increasing coexistence between deer and humans and/or domestic animals, dictates an adequate knowledge of the potential infectious diseases carried by free-ranging wild ungulates.

Author Contributions: Conceptualization, S.C., A.C. and C.B.; methodology, A.C., M.C. and C.B.; validation M.C., V.S., A.C.; formal analysis, A.C., M.C., E.D.L.; investigation, M.C., A.C., E.D.L. and R.R.; resources, C.B., R.R. and S.C.; data curation, A.C., C.B. and V.S.; writing-original draft preparation, A.C., C.B., S.C., V.S., R.R.; writing-review and editing, A.C., C.B. and S.C.; supervision, A.C., C.B. and S.C. All authors have read and agreed to the published version of the manuscript.

Funding: The authors acknowledge support from the University of Milan through the APC initiative.

Institutional Review Board Statement: Animal samples were collected in the context of the rescue activities of the Piacenza Wildlife Rescue Center. According to the guidelines of the authors' institution (University of Milan), a formal approval of the Ethical Committee was not required (EC decision 29 October 2012, renewed with the protocol no. 02-2016).

Data Availability Statement: The nucleotide sequences generated in this study from Babesia spp. partial 18S rDNA gene (OK598971-OK598982) and Anaplasma phagocytophilum partial 16S rDNA gene (OK597195-OK597196) were deposited in GenBank (NCBI).

Acknowledgments: The authors would like to thank the Piacenza Wildlife Rescue Center for providing the samples used in this study.

Conflicts of Interest: The authors declare no conflict of interest.

\section{References}

1. Vu Hai, V.; Almeras, L.; Socolovschi, C.; Raoult, D.; Parola, P.; Pagès, F. Monitoring human tick-borne disease risk and tick bite exposure in Europe: Available tools and promising future methods. Ticks Tick-Borne Dis. 2014, 5, 607-619. [CrossRef]

2. Medlock, J.M.; Hansford, K.M.; Bormane, A.; Derdakova, M.; Estrada-Peña, A.; George, J.-C.; Golovljova, I.; Jaenson, T.G.T.; Jensen, J.-K.; Jensen, P.M.; et al. Driving Forces for changes in geographical distribution of Ixodes ricinus ticks in Europe. Parasit. Vectors 2013, 6, 1. [CrossRef] [PubMed]

3. Ogden, N. Changing Geographic ranges of ticks and tick-borne pathogens: Drivers, mechanisms and consequences for pathogen diversity. Front. Cell. Infect. Microbiol. 2013, 3. [CrossRef] [PubMed]

4. Ruiz-Fons, F.; Fernández-de-Mera, I.G.; Acevedo, P.; Gortázar, C.; de la Fuente, J. Factors driving the abundance of Ixodes ricinus ticks and the prevalence of zoonotic I. ricinus-borne pathogens in natural foci. Appl. Environ. Microbiol. 2012, 78, $2669-2676$. [CrossRef]

5. Carpio, A.J.; Apollonio, M.; Acevedo, P. Wild ungulate overabundance in Europe: Contexts, causes, monitoring and management recommendations. Mammal Rev. 2021, 51, 95-108. [CrossRef]

6. Apollonio, M.; Andersen, R.; Putman, R. European Ungulates and Their Management in the 21st Century; Cambridge University Press: Cambridge, UK, 2010; ISBN 978-0-521-76061-4.

7. De Pasquale, D.; Dondina, O.; Scancarello, E.; Meriggi, A. Long-term viability of a reintroduced population of roe deer Capreolus capreolus, in a lowland area of northern Italy. Folia Zool. 2019, 68, 9-20. [CrossRef]

8. Randi, E. Management of wild ungulate populations in Italy: Captive-breeding, hybridisation and genetic consequences of translocations. Vet. Res. Commun. 2005, 29, 71-75. [CrossRef]

9. Randi, E.; Alves, P.C.; Carranza, J.; Milošević-Zlatanović, S.; Sfougaris, A.; Mucci, N. Phylogeography of roe deer (Capreolus capreolus) populations: The effects of historical genetic subdivisions and recent nonequilibrium dynamics. Mol. Ecol. 2004, 13, 3071-3083. [CrossRef]

10. Stuen, S. Anaplasma phagocytophilum-the most widespread tick-borne infection in animals in Europe. Vet. Res. Commun. 2007, 31, 79-84. [CrossRef]

11. Woldehiwet, Z. Immune evasion and immunosuppression by Anaplasma phagocytophilum, the causative agent of tick-borne fever of ruminants and human granulocytic anaplasmosis. Vet. J. 2008, 175, 37-44. [CrossRef]

12. Ravnik, U.; Tozon, N.; Strasek, K.; Zupanc, T.A. Clinical and haematological features in Anaplasma phagocytophilum seropositive dogs. Clin. Microbiol. Infect. 2009, 15, 39-40. [CrossRef] [PubMed]

13. Stuen, S.; Olsson Engvall, E.; Artursson, K. Persistence of Ehrlichia phagocytophila infection in lambs in relation to clinical parameters and antibody responses. Vet. Rec. 1998, 143, 553-555. [CrossRef] [PubMed]

14. Kogler, S.; Gotthalmseder, E.; Shahi-Barogh, B.; Harl, J.; Fuehrer, H.-P. Babesia spp. and Anaplasma phagocytophilum in free-ranging wild ungulates in central Austria. Ticks Tick-Borne Dis. 2021, 12, 101719. [CrossRef] [PubMed]

15. Overzier, E.; Pfister, K.; Herb, I.; Mahling, M.; Böck, G.; Silaghi, C. Detection of tick-borne pathogens in roe deer (Capreolus capreolus), in questing ticks (Ixodes ricinus), and in ticks infesting roe deer in southern Germany. Ticks Tick-Borne Dis. 2013, 4, 320-328. [CrossRef] 
16. Sun, Y.; Li, S.-G.; Jiang, J.-F.; Wang, X.; Zhang, Y.; Wang, H.; Cao, W.-C. Babesia venatorum infection in child, China. Emerg. Infect. Dis. 2014, 20, 896-897. [CrossRef]

17. Malandrin, L.; Jouglin, M.; Sun, Y.; Brisseau, N.; Chauvin, A. Redescription of Babesia capreoli (Enigk and Friedhoff, 1962) from roe deer (Capreolus capreolus): Isolation, cultivation, host specificity, molecular characterisation and differentiation from Babesia divergens. Int. J. Parasitol. 2010, 40, 277-284. [CrossRef]

18. Häselbarth, K.; Tenter, A.M.; Brade, V.; Krieger, G.; Hunfeld, K.-P. First case of human babesiosis in Germany-Clinical presentation and molecular characterisation of the pathogen. Int. J. Med. Microbiol. 2007, 297, 197-204. [CrossRef]

19. Fonseca, M.S.; Bahiense, T.C.; Silva, A.A.B.; Onofrio, V.C.; Barral, T.D.; Souza, B.M.P.; Lira-da-Silva, R.M.; Biondi, I.; Meyer, R.; Portela, R.W. Ticks and associated pathogens from rescued wild animals in rainforest fragments of northeastern Brazil. Front. Vet. Sci. 2020, 7, 177. [CrossRef]

20. Szekeres, S.; van Leeuwen, A.D.; Tóth, E.; Majoros, G.; Sprong, H.; Földvári, G. Road-killed mammals provide insight into tick-borne bacterial pathogen communities within urban habitats. Transbound. Emerg. Dis. 2019, 66, 277-286. [CrossRef]

21. Chianucci, F.; Mattioli, L.; Amorini, E.; Giannini, T.; Marcon, A.; Chirichella, R.; Apollonio, M.; Cutini, A. Early and long-term impacts of browsing by roe deer in oak coppiced woods along a gradient of population density. Ann. Silvic. Res. 2015, 39. [CrossRef]

22. Dondina, O.; Orioli, V.; Chiatante, G.; Meriggi, A.; Bani, L. Species specialization limits movement ability and shapes ecological networks: The case study of 2 forest mammals. Curr. Zool. 2019, 65, 237-249. [CrossRef]

23. Putzu, N.; Bonetto, D.; Civallero, V.; Fenoglio, S.; Meneguz, P.G.; Preacco, N.; Tizzani, P. Temporal patterns of ungulate-vehicle collisions in a subalpine Italian region. Ital. J. Zool. 2014, 81, 463-470. [CrossRef]

24. Bonnot, N.; Morellet, N.; Verheyden, H.; Cargnelutti, B.; Lourtet, B.; Klein, F.; Hewison, A.J.M. Habitat use under predation risk: Hunting, roads and human dwellings influence the spatial behaviour of roe deer. Eur. J. Wildl. Res. 2013, 59, 185-193. [CrossRef]

25. Riga, F.; Genghini, M.; Cascone, C.; Di Luzio, P. Impatto Degli Ungulati Sulle Culture Agricole a Forestali Proposta per Linee Guida Nazionali; Manuali e Linee Guida ISPRA; ISPRA Publ.: Rome, Italy, 2011; Volume 68.

26. Di Lorenzo, E.; Rossi, R.; Ferrari, F.; Martini, V.; Comazzi, S. Blood L-lactate concentration as an indicator of outcome in roe deer (Capreolus capreolus) admitted to a wildlife rescue center. Animals 2020, 10, 1066. [CrossRef] [PubMed]

27. Fajardo, V.; González, I.; Martín, I.; Rojas, M.; Hernández, P.E.; García, T.; Martín, R. Real-time PCR for detection and quantification of red deer (Cervus elaphus), fallow deer (Dama dama), and roe deer (Capreolus capreolus) in meat mixtures. Meat Sci. 2008, 79, 289-298. [CrossRef]

28. Casati, S.; Sager, H.; Gern, L.; Piffaretti, J.-C. Presence of potentially pathogenic Babesia sp. for human in Ixodes ricinus in Switzerland. Ann. Agric. Environ. Med. AAEM 2006, 13, 65-70.

29. Aktas, M.; Altay, K.; Dumanli, N.; Kalkan, A. Molecular detection and identification of Ehrlichia and Anaplasma species in ixodid ticks. Parasitol. Res. 2009, 104, 1243. [CrossRef] [PubMed]

30. Gouy, M.; Guindon, S.; Gascuel, O. SeaView Version 4: A Multiplatform graphical user interface for sequence alignment and phylogenetic tree building. Mol. Biol. Evol. 2010, 27, 221-224. [CrossRef]

31. Cafiso, A.; Olivieri, E.; Floriano, A.M.; Chiappa, G.; Serra, V.; Sassera, D.; Bazzocchi, C. Investigation of tick-borne pathogens in Ixodes ricinus in a peri-urban park in Lombardy (Italy) reveals the presence of emerging pathogens. Pathogens 2021, 10, 732. [CrossRef] [PubMed]

32. Kimura, M. A simple method for estimating evolutionary rates of base substitutions through comparative studies of nucleotide sequences. J. Mol. Evol. 1980, 16, 111-120. [CrossRef]

33. Kumar, S.; Stecher, G.; Li, M.; Knyaz, C.; Tamura, K. MEGA X: Molecular Evolutionary Genetics Analysis across computing platforms. Mol. Biol. Evol. 2018, 35, 1547-1549. [CrossRef] [PubMed]

34. Social Science Statistics. Available online: https://www.socscistatistics.com/ (accessed on 26 October 2021).

35. Remesar, S.; Díaz, P.; Prieto, A.; García-Dios, D.; Fernández, G.; López, C.M.; Panadero, R.; Díez-Baños, P.; Morrondo, P. Prevalence and molecular characterization of Anaplasma phagocytophilum in roe deer (Capreolus capreolus) from Spain. Ticks Tick-Borne Dis. 2020, 11, 101351. [CrossRef] [PubMed]

36. Tampieri, M.P.; Galuppi, R.; Bonoli, C.; Cancrini, G.; Moretti, A.; Pietrobelli, M. Wild ungulates as Babesia hosts in northern and central Italy. Vector-Borne Zoonotic Dis. 2008, 8, 667-674. [CrossRef]

37. Duh, D.; Petrovec, M.; Avsic-Zupanc, T. Diversity of Babesia infecting european sheep ticks (Ixodes ricinus). J. Clin. Microbiol. 2001, 39, 3395-3397. [CrossRef]

38. Hoby, S.; Mathis, A.; Doherr, M.G.; Robert, N.; Ryser-Degiorgis, M.-P. Babesia capreoli infections in alpine chamois (Rupicapra r. rupicapra), roe deer (Capreolus c. capreolus) and red deer (Cervus elaphus) from Switzerland. J. Wildl. Dis. 2009, 45, 748-753. [CrossRef]

39. Kauffmann, M.; Rehbein, S.; Hamel, D.; Lutz, W.; Heddergott, M.; Pfister, K.; Silaghi, C. Anaplasma phagocytophilum and Babesia spp. in roe deer (Capreolus capreolus), fallow deer (Dama dama) and mouflon (Ovis musimon) in Germany. Mol. Cell. Probes 2017, 31, 46-54. [CrossRef] [PubMed]

40. Silaghi, C.; Hamel, D.; Pfister, K.; Rehbein, S. Babesia species and co-infection with Anaplasma phagocytophilum in free-ranging ungulates from Tyrol. Tierärztliche Mschr. Vet. Med. Austria 2011, 98, 268-274.

41. Andersson, M.O.; Bergvall, U.A.; Chirico, J.; Christensson, M.; Lindgren, P.-E.; Nordström, J.; Kjellander, P. Molecular detection of Babesia capreoli and Babesia venatorum in wild Swedish roe deer, Capreolus capreolus. Parasit. Vectors 2016, 9, 221. [CrossRef] 
42. Gray, A.; Capewell, P.; Loney, C.; Katzer, F.; Shiels, B.R.; Weir, W. Sheep as host species for zoonotic Babesia venatorum, United Kingdom. Emerg. Infect. Dis. 2019, 25, 2257-2260. [CrossRef]

43. Zanet, S.; Trisciuoglio, A.; Bottero, E.; de Mera, I.G.F.; Gortazar, C.; Carpignano, M.G.; Ferroglio, E. Piroplasmosis in wildlife: Babesia and Theileria affecting free-ranging ungulates and carnivores in the Italian Alps. Parasit. Vectors 2014, 7, 70. [CrossRef]

44. Hoby, S.; Robert, N.; Mathis, A.; Schmid, N.; Meli, M.L.; Hofmann-Lehmann, R.; Lutz, H.; Deplazes, P.; Ryser-Degiorgis, M.-P. Babesiosis in free-ranging chamois (Rupicapra r. rupicapra) from Switzerland. Vet. Parasitol. 2007, 148, 341-345. [CrossRef] [PubMed]

45. Penzhorn, B.L. Babesiosis of wild carnivores and ungulates. Vet. Parasitol. 2006, 138, 11-21. [CrossRef]

46. Fanelli, A. A historical review of Babesia spp. associated with deer in Europe: Babesia divergens /Babesia divergens-like, Babesia capreoli, Babesia venatorum, Babesia cf. odocoilei. Vet. Parasitol. 2021, 294, 109433. [CrossRef] [PubMed]

47. Aureli, S.; Galuppi, R.; Ostanello, F.; Foley, J.E.; Bonoli, C.; Rejmanek, D.; Rocchi, G.; Orlandi, E.; Tampieri, M.P. Abundance of questing ticks and molecular evidence for pathogens in ticks in three parks of Emilia-Romagna region of northern Italy. Ann. Agric. Environ. Med. 2015, 22, 459-466. [CrossRef] [PubMed]

48. Herwaldt, B.L.; Cacciò, S.; Gherlinzoni, F.; Aspöck, H.; Slemenda, S.B.; Piccaluga, P.; Martinelli, G.; Edelhofer, R.; Hollenstein, U.; Poletti, G.; et al. Molecular Characterization of a non-Babesia divergens organism causing zoonotic babesiosis in Europe. Emerg. Infect. Dis. 2003, 9, 943-948. [CrossRef]

49. Zhao, L.; Jiang, R.; Jia, N.; Ning, N.; Zheng, Y.; Huo, Q.; Sun, Y.; Yuan, T.; Jiang, B.; Li, T.; et al. Human case infected with Babesia venatorum: A 5-year follow-up study. Open Forum Infect. Dis. 2020, 7. [CrossRef]

50. Michel, A.O.; Mathis, A.; Ryser-Degiorgis, M.-P. Babesia spp. in European wild ruminant species: Parasite diversity and risk factors for infection. Vet. Res. 2014, 45, 65. [CrossRef]

51. Razanske, I.; Rosef, O.; Radzijevskaja, J.; Bratchikov, M.; Griciuviene, L.; Paulauskas, A. Prevalence and co-infection with tick-borne Anaplasma phagocytophilum and Babesia spp. in red deer (Cervus elaphus) and roe deer (Capreolus capreolus) in southern Norway. Int. J. Parasitol. Parasites Wildl. 2019, 8, 127-134. [CrossRef]

52. Di Domenico, M.; Pascucci, I.; Curini, V.; Cocco, A.; Dall'Acqua, F.; Pompilii, C.; Cammà, C. Detection of Anaplasma phagocytophilum genotypes that are potentially virulent for human in wild ruminants and Ixodes ricinus in central Italy. Ticks Tick-Borne Dis. 2016, 7, 782-787. [CrossRef] [PubMed]

53. Ebani, V.V.; Cerri, D.; Fratini, F.; Ampola, M.; Andreani, E. Anaplasma phagocytophilum infection in a fallow deer (Dama dama) population in a preserve of central Italy. New Microbiol. 2007, 30, 161-165.

54. Grassi, L.; Franzo, G.; Martini, M.; Mondin, A.; Cassini, R.; Drigo, M.; Pasotto, D.; Vidorin, E.; Menandro, M.L. Ecotyping of Anaplasma phagocytophilum from wild ungulates and ticks shows circulation of zoonotic strains in northeastern Italy. Animals 2021, 11, 310. [CrossRef]

55. Carpi, G.; Bertolotti, L.; Pecchioli, E.; Cagnacci, F.; Rizzoli, A. Anaplasma phagocytophilum groEL gene heterogeneity in Ixodes ricinus larvae feeding on roe deer in northeastern Italy. Vector-Borne Zoonotic Dis. 2008, 9, 179-184. [CrossRef]

56. Hornok, S.; Sugár, L.; Fernández de Mera, I.G.; de la Fuente, J.; Horváth, G.; Kovács, T.; Micsutka, A.; Gönczi, E.; Flaisz, B.; Takács, N.; et al. Tick- and fly-borne bacteria in ungulates: The prevalence of Anaplasma phagocytophilum, haemoplasmas and rickettsiae in water buffalo and deer species in central Europe, Hungary. BMC Vet. Res. 2018, 14, 98. [CrossRef]

57. Jahfari, S.; Coipan, E.C.; Fonville, M.; van Leeuwen, A.D.; Hengeveld, P.; Heylen, D.; Heyman, P.; van Maanen, C.; Butler, C.M.; Földvári, G.; et al. Circulation of four Anaplasma phagocytophilum ecotypes in Europe. Parasit. Vectors 2014, 7, 365. [CrossRef]

58. Huhn, C.; Winter, C.; Wolfsperger, T.; Wüppenhorst, N.; Smrdel, K.S.; Skuballa, J.; Pfäffle, M.; Petney, T.; Silaghi, C.; Dyachenko, V.; et al. Analysis of the population structure of Anaplasma phagocytophilum using multilocus sequence typing. PLoS ONE 2014, 9, e93725. [CrossRef]

59. Dugat, T.; Lagrée, A.-C.; Maillard, R.; Boulouis, H.-J.; Haddad, N. Opening the black box of Anaplasma phagocytophilum diversity: Current situation and future perspectives. Front. Cell. Infect. Microbiol. 2015, 5, 61. [CrossRef]

60. Silaghi, C.; Fröhlich, J.; Reindl, H.; Hamel, D.; Rehbein, S. Anaplasma phagocytophilum and Babesia species of sympatric roe deer (Capreolus capreolus), fallow deer (Dama dama), sika deer (Cervus nippon) and red deer (Cervus elaphus) in Germany. Pathogens 2020, 9, 968. [CrossRef] [PubMed]

61. Brown, W.C.; Barbet, A.F. Persistent infections and immunity in ruminants to arthropod-borne bacteria in the family Anaplasmataceae. Annu. Rev. Anim. Biosci. 2016, 4, 177-197. [CrossRef] [PubMed]

62. Bastian, S.; Jouglin, M.; Brisseau, N.; Malandrin, L.; Klegou, G.; L'Hostis, M.; Chauvin, A. Antibody prevalence and molecular identification of Babesia spp. in roe deer in France. J. Wildl. Dis. 2012, 48, 416-424. [CrossRef] [PubMed] 